\title{
Settlement of Thick Clay Deposits under Piled-Raft Foundation and Design Considerations (Pile Dimensions)
}

\author{
Lee, K.Y. ${ }^{1}$
}

\begin{abstract}
Characteristics and histories of the deltaic deposits in geotechnical perspective are studied. Geotechnical issues of clay deposits under floating foundation systems also analyzed. Theoretical expressions and parameters were examined by an experimental study and numerical analysis on the laboratory scales and field measurement in this study. Also, piled raft foundation on thick clay deposits is designated to optimize pile configuration. The predictions of settlements of piled rafts foundation are proposed based on pile dimensions by utilizing a normalized $\mathrm{A}_{\mathrm{p}} / \mathrm{nL}$ and $\mathrm{B}_{\mathrm{g}} / \mathrm{B}_{\mathrm{r}}$. Practical design of piled raft foundations is made for the light bridges and five story buildings on thick clay deposits to discuss the long-term settlement, and it is found that the piled raft is well applicable and effective on thick clay deposits, and that differential settlements of the foundation should be managed by designing the configuration of pile lengths and spacing.
\end{abstract}

Keywords: Thick deltaic deposits; settlement; piled-raft; light-weight foundation; width ratio.

\section{Introduction}

Design of foundation comprises of settlement and bearing capacity, which are influenced by its soilstructure interactions. In spite of using 3D FEM software to rigorously cover the interactions, some attempts have been made to reduce the complexity of the interactions to propose much simpler and faster estimations for settlement and bearing capacity.

\section{Soil-Structure Interactions}

Piled raft foundation is a type of foundation which takes into account three components (pile group, raft, and subsoil) to resist the design load subjected to it. In comparison with the conventional foundation design, piled raft foundation exhibits a total new dimension for the soil-structure interaction because of the new design philosophy to utilize the pile group up to their ultimate bearing capacities [1]. There are four major soil-structure interactions on piled raft foundation that bind the overall performance of the foundation system. Those interactions are indeed very complex, so that one should consider modeling by numerical analysis that allows the most rigorous treatment for the soil-structure interactions [2]. These four major soil-structure interaction, in addition, have been contributing continuously to the development of precise numerical modeling for piled raft foundation.

The load transferred to the piled raft system creates interactions among its parts (raft, pile group, and surrounding soils). First, the pile-soil interaction can

1 Department of Civil Engineering, Dongseo University, Busan, KOREA.Email: civklee@dongseo.ac.kr,kylee913@gmail.com be simply thought as frictional resistance with the possibilities for undergoing slip and negative skin friction. In this interaction, shear modulus plays an important role rather than Young's modulus. Second, the pile-pile interaction is simply dependent on the pile spacing, number, and length [3] that may affect the efficiency of bearing capacity of piles. Third, the raft-soil interaction reveals the bearing capacity considering net contact between raft and soil that is usually satisfactory in safety. In this interaction, Young's modulus of soil is more dominant when there is no significant horizontal load and pile spacing is relatively long. Finally, the pile-raft interaction will determine in the design; proportion of load sharing and reduction of settlement. Eventually, the soil-structure interactions mentioned previously, are dependent on each other. This emphasizes how complex they are in the reality.

The soil structure interactions on piled raft foundation can be simplified to that of piles and raft only. This simplification is then used to compose the design philosophy of piled raft foundation. Poulos in 2001 [4] summaries the different design philosophies for piled raft foundation as follows:

1. Piles are mainly designed to take up the majority of foundation loads and the raft only carries a small proportion of the total load.

2. The raft is designed to resist the foundation loads and piles carry a small proportion of the total load. The piles are placed strategically to reduce differential settlement.

3. The raft is designed to take up the majority of foundation loads. The piles are then designed to reduce the net contact pressure between the raft and the soils to a level below the pre-consolidation pressure of the soil. 


\section{Bearing Resistant}

The interaction behavior of raft and pile group can be described by examining the load sharing between them. It is obvious that load taken by the raft may reduce due to the presence of piles as ground stiffener. Reul [3] has conducted some numerical studies on un-piled raft $(R)$, free-standing pile group $(F P G)$, and piled raft $(P R)$ foundations to see the phenomena of load sharing. In addition, free-standing pile group (FGP) is a type of foundations without considering any of bearing portion of raft (or cap). In case of piled raft foundation (RP), Reul showed that, the more the number of pile installed, the bigger the load portion taken by the group of pile [3].

Figures 1 and 2 show a numerical study of progress of load sharing of a piled raft foundation $\left(E_{p}=30000\right.$ $\mathrm{MPa}, v_{p}=0.15, E_{r}=25743 \mathrm{MPa}, v_{r}=0.15$, and pile group is configured symmetrically from the center of the raft) by using 2D plain strain FEM analysis. Obviously, results depicted in Figure 1 are in good agreement with the study performed by Reul [3] that the pile resistances will be greater than the resistance of raft as the settlement progresses. Simulating that the raft is in direct contact with the soil will show higher portion of load taken by the raft at early stage and slowly reduce as the pile resistances are mobilized (Figure 2). In addition, "with a reduction of interface strength" refers to slip at the interface of soil and pile taken into account. Oppositely, "without a reduction of interface strength" means interface strength of soil and pile is the same as that of soil.

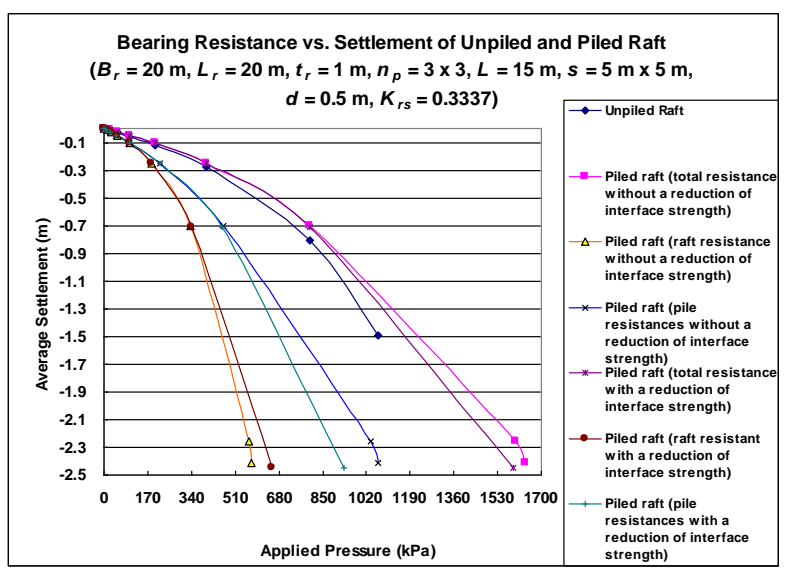

Figure 1. Bearing Resistance vs. Settlement on Raft and Piled Raft Foundations

\section{Settlement Behavior of Piled Raft}

Regarding the effect of raft and pile group interaction on the settlement of square piled raft, it means that the settlement of piled raft foundation decreases due to smaller net contact pressure between the raft and the soil. For a given piled raft, settlement cannot be smaller than a certain value, depending on the pile configuration and the load level [3].

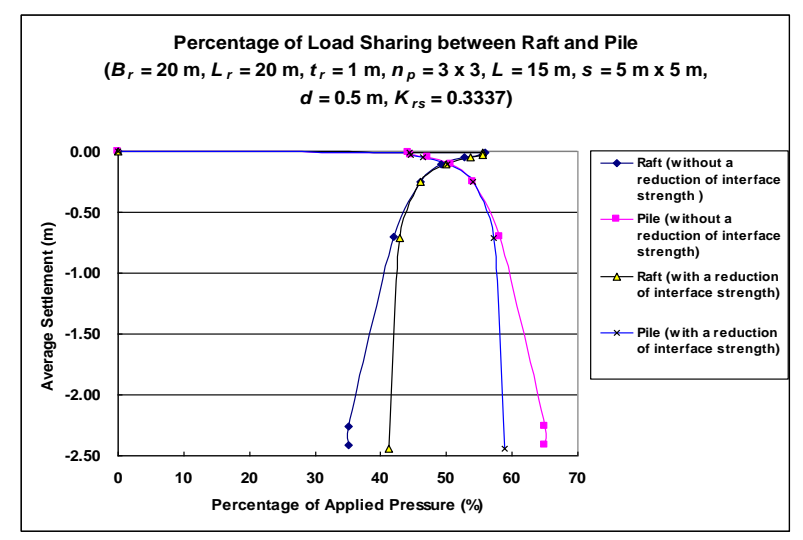

Figure 2. Proportion of Load Taken by Raft and Piles

The concept of reducing the settlement can be done readily by increasing the length of pile, while controlling the number of pile to be placed at strategic area bellow the raft.

\section{Simplified Load-Settlement Curve}

Calculation of the average settlement for piled raft foundation from a simplified load-settlement curve of the foundation system itself is described by Poulos and Davis [5] in Figure 3. The piles, at first, will undergo un-drained loading until their failure capacities are reached (point A in Figure 3) and the raft (or cap) will take the remaining load so that the additional un-drained settlement would be caused by the raft only. The working load applied on the system (point $\mathrm{C}$ in Figure 3) is assumed to be located in between points A and B. Furthermore, the superstructure loading may progress until the system fails (point B in Figure 3) which shows the summation of the piles (individual or block) and raft capacities.

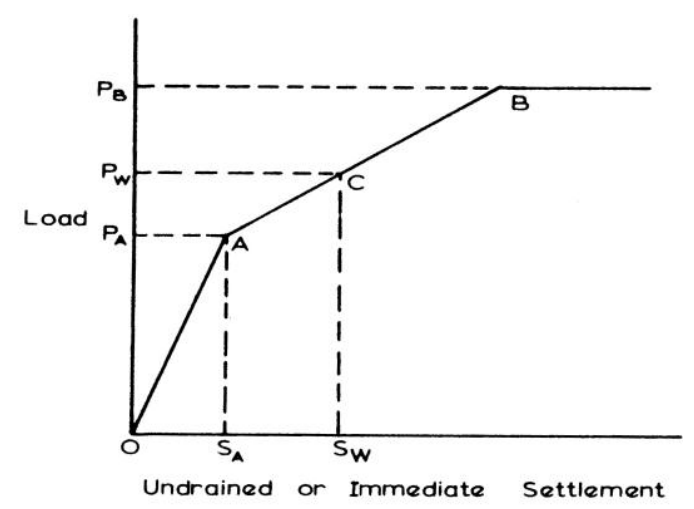

Figure 3. Simplified Load-Settlement Curve of Piled Raft Foundation [5]

The average immediate settlement $\left(\rho_{w}\right)$ at working load $\left(P_{W}\right)$ for a square rigid raft $B_{r} \times B_{r}$, is given in Equation 1 (un-drained condition) where $P_{W}>P_{A}$ (Figure 3). Furthermore, the consolidation settlement of piled raft foundation can be estimated using Equation 2, as well as the total settlement (immediate and consolidation) using Equation $5\left(\rho_{w t}\right)$. 
Line OAC (Figure 3):

$$
\rho_{w}=P_{A} R_{G 0.5} \rho_{1}+\frac{0.947\left(P_{W}-P_{A}\right)\left(1-v_{u}{ }^{2}\right)}{B_{r} E_{u}}
$$

where:

$\rho_{w}=$ total undrained immediate settlement under working load [m].

$P_{A}=$ ultimate capacity of pile group (block or individual failure) $[\mathrm{kN}]$.

$R_{G 0.5}=$ undrained group settlement factor.

$\rho_{1}=$ immediate settlement of a single pile under unit load.

$P_{W}=$ working load $[\mathrm{kN}]$.

$v_{u}=$ undrained Poisson's ratio.

$B_{r} \quad=$ width of raft $[\mathrm{m}]$.

$E_{u}=$ undrained modulus of soil $[\mathrm{kPa}]$.

The origin of the number 0.947 (termed as immediate settlement coefficient) appears in Equation 1 can be referred to Harr [6]. The other values can be also referred to the same author, for the immediate settlement coefficient which depend on width of the raft $\left(B_{r}\right)$, length of the raft $\left(L_{r}\right)$, depth of embedment $\left(D_{f}\right)$, and the presence of hard layer beneath the foundation system. It should be mentioned that Equation 1 does not consider the effects of local slip along the pile group or local yield of the raft as the load increases toward failure. In addition, the consolidation settlement $\left(\rho_{C F}\right)$ assumes that the consolidation process is not affected by any local yielding occurring under undrained condition. Equations 2-4 will then yield a correct value of consolidation settlement $\left(\rho_{C F}\right)$ for limiting cases of the raft only and of the rigid block and for those systems in which the failure load of the pile group is not reached. It is therefore reasonable to assume that satisfactory results will be obtained for other cases involving piles that have slipped.

$$
\begin{aligned}
& \rho_{C F}=\rho_{T F e}-\rho_{i e} \\
& \rho_{T F e}=P_{W} R_{G v^{\prime}} \rho_{1 T F} \\
& \rho_{i e}=P_{W} R_{G 0.5} \rho_{1 i} \\
& \rho_{w t}=P_{A} R_{G 0.5} \rho_{1}+\frac{0.71\left(P_{W}-P_{A}\right)}{B E_{u}}+\rho_{C F}
\end{aligned}
$$

where:

$\rho_{C F}=$ consolidation settlement of foundation [m].

$\rho_{\text {TFe }}=$ total settlement (immediate + consolidation settlements) of foundation [m].

$\rho_{1 T F}=$ total settlement (immediate + consolidation settlements) of a single pile under unit load

$\rho_{1 i}=\rho_{1}$ (Equation 1$)=$ immediate settlement of a single pile under unit load [m].

$\rho_{i e}=$ total immediate settlement of piled raft foundation $[\mathrm{m}]$.

$R_{G v^{\prime}}=$ group settlement factor with $v_{s}=v^{\prime}$.
The following review will be focused on describing the practical methods to estimate the settlement of piled raft foundation as the primary theoretical review of this paper. It will include the immediate average and differential settlements, for piled rafts with uniform length and spacing.

\section{Elastic Continuum Method}

Fleming et al. [7] presented a simple method for analyzing the combined stiffness of the raft and the pile group, which allows the interaction between them. For a piled raft where the raft bears on competent stratum, the approach of combining the separate stiffness of the raft and the pile group using an elastic continuum method is based on the use of average interaction factor $\left(\alpha_{c p}\right)$ between the pile group and the raft. The overall foundation stiffness is given in Equation 6 [7].

$$
K_{p r}=\frac{K_{p}+K_{r}\left(1-2 \alpha_{c p}\right)}{1-\alpha_{c p}{ }^{2} \frac{K_{r}}{K_{p}}}
$$

where:

$K_{p r}=$ stiffness of piled raft foundation $[\mathrm{kN} / \mathrm{m}]$.

$K_{p}=$ stiffness of pile group $=R_{g} n_{p} K_{1}[\mathrm{kN} / \mathrm{m}]$.

$K_{1}=$ stiffness of single pile under average vertical load $[\mathrm{kN} / \mathrm{m}]$.

$R_{g}=$ stiffness efficiency factor.

$K_{r}=$ stiffness of raft, assuming rigid raft [5] = $\frac{2.25 G_{s} \sqrt{A_{r}}}{\left(1-v_{s}\right)}[\mathrm{kN} / \mathrm{m}]$

$A_{r}=$ area of the raft $\left[\mathrm{m}^{2}\right]$.

$G_{s}=$ shear modulus of soil $[\mathrm{kPa}]$.

$v_{s}=$ Poisson's ratio of soil.

$a_{c p}=$ average interaction factor $=\frac{\ln \left(r_{m} / r_{o}\right)}{\ln \left(r_{m} / r_{r}\right)}$.

$r_{m}=$ radius influence of pile $\approx$ length of pile $[\mathrm{m}]$.

$r_{o}=$ radius of pile $[\mathrm{m}]$.

$r_{r}=$ equivalent radius of the pile associated with each pile $=\sqrt{\frac{A_{r}}{\pi n_{p}}}[\mathrm{~m}]$.

$n_{p}=$ number of pile.

Equation 7 [8] furthermore, can be used to determine the stiffness (load/settlement $\sim[\mathrm{kN} / \mathrm{m}]$ ) of a single pile $\left(K_{1}\right)$ under average vertical load (i.e. total load divided by number of pile) for all condition of pile slenderness ratio $(L / d)$. In addition, remarks for $G$ properties in Equation 7 can be seen in Figure 4.

$K_{1}=\left(\frac{\frac{4 \eta}{\left(1-v_{s}\right) \xi}+\rho \frac{2 \pi}{\zeta} \frac{\tanh (\mu L)}{u L} \frac{L}{r_{o}}}{1+\frac{1}{\pi \lambda} \frac{4 \eta}{\left(1-v_{s}\right) \xi} \frac{\tanh (\mu L)}{\mu L} \frac{L}{r_{o}}}\right) \times G_{L} \times r_{o}$ 
where:

$\eta=r_{b} / r_{o}$.

$r_{o}=$ radius of pile above the pile base $[\mathrm{m}]$.

$r_{b}=$ radius of pile at the pile base $[\mathrm{m}]$.

$\rho=G_{0.5 L} / G_{L}=G_{a v g} / G_{L}$.

$\xi=G_{L} / G_{b}$.

$\lambda=$ pile stiffness ratio $=E_{p} / G_{L}$.

$\mu L=$ pile compressibility $=\sqrt{2 / \zeta \lambda} \frac{L}{r_{o}}$.

$\zeta=$ load transfer parameter.

$$
=\ln \left\{\left[0.25+\left(2.5 \rho\left(1-v_{s}\right)-0.25\right) \xi\right] \frac{L}{r_{o}}\right\} .
$$

$E_{p}=$ elastic modulus of pile $[\mathrm{kPa}]$.

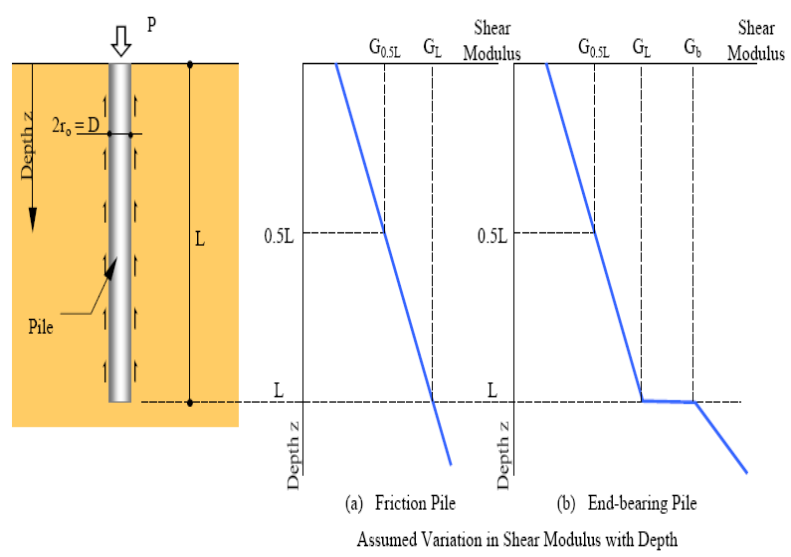

Figure 4. G Properties for Stiffness of A Single Pile [9]

Different pile stiffness may be caused by different pile slenderness ratio $(L / d)$. Table 1 shows the more precise characteristic of pile stiffness with pile slenderness ratio $(L / d)$. Eventually, the settlement profile $(\delta)$ with depth $(\mathrm{z})$ can be estimated using Equation 8 [7].

$\delta=\delta_{b} \cosh (\mu(L-z))$

where:

$\delta_{b}=$ settlement at the pile base [m].

$$
=\frac{P_{b}\left(1-v_{s}\right)}{4 r_{b} G_{b}} \text {. }
$$

$P_{b}=$ load at the pile base (definition for the following notations have been previously given).

$$
P_{b}=\frac{\frac{4 \eta}{\left(1-v_{s}\right) \xi} \frac{1}{\cosh (\mu L)}}{\frac{4 \eta}{\left(1-v_{s}\right) \xi}+\frac{2 \pi \rho}{\zeta} \frac{\tanh (\mu L)}{\mu L} \frac{L}{r_{o}}} \times P_{t}[\mathrm{kN}] .
$$

$P_{t}=$ total load applied on the pile group $[\mathrm{kN}]$.

$r_{b}=$ radius of pile at the pile base $[\mathrm{m}]$.

$G_{b}=$ shear modulus of soil at the pile base $[\mathrm{kPa}]$.

$v_{s}=$ Poisson's ratio of soil.

$\rho=G_{0.5 L} / G_{L}=G_{a v g} / G_{L}$.
Table 1. Pile Group Stiffness with Different Slenderness Ratio $(L / d)$ of Pile [7]

\begin{tabular}{ll}
\hline$L / d \leq 0.25 \sqrt{E_{p} / G_{L}}$ & $L / d \geq 1.5 \sqrt{E_{p} / G_{L}}$ \\
\hline $\begin{array}{ll}\text { Pile may be treated as } \\
\text { effectively rigid }\end{array}$ & $\begin{array}{l}\text { Pile may be treated as } \\
\text { infinitely long. }\end{array}$ \\
$K_{1}=\left(\frac{4 \eta}{\left(1-v_{s}\right) \xi}+\frac{2 \pi \rho L}{r_{o}}\right) \times G_{L} \times r_{o}$ & $K_{1}=\left(\pi \rho \sqrt{\frac{2 \lambda}{\zeta}}\right) \times G_{L} \times r_{o}$ \\
$(\mathrm{kN} / \mathrm{m})$ &
\end{tabular}

Note: this formula must be combined with equivalent pier method.

$(\mathrm{kN} / \mathrm{m})$

$G_{L}$ is shear modulus of soil at the bottom of active pile length $L_{a c}$, where:

$L_{a c}=3 r_{o} \sqrt{E_{p} / G_{L}}$

$(\mathrm{m})$.

Note: all notation definitions in Table 1 have been previously described in this chapter.

Adopting the same derivation for the pile raft stiffness $\left(K_{p r}\right)$ as described by Fleming et al. [7], Clancy and Randolph [10] have reported from a more rigorous analysis that as the size of pile group size increases, the interaction factor $\left(a_{c p}\right)$ tends towards a constant value of 0.8 (Figure 5), independent on pile spacing $(s)$, slenderness ratio $(L / d)$, or stiffness ratio $\left(\lambda=E_{p} / E_{s}\right)$.

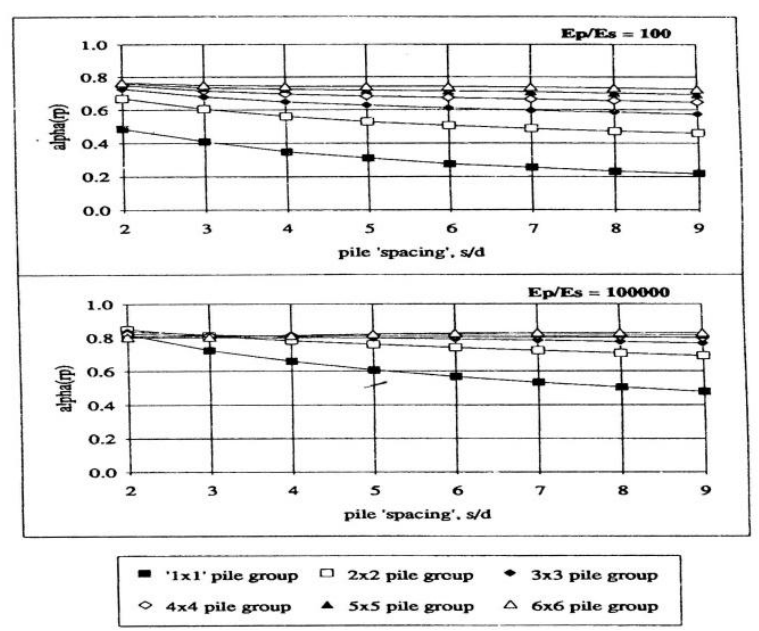

Figure 5. Interaction Factor, $a_{r p}\left(=\alpha_{c p}\right)$ for Various Size of Pile Group (After Clancy and Randolph, [10])

Based on this fact, the formulation given in Equation 7 can be simplified to Equation 9. Other procedures such as finding $K_{r}[\mathrm{kN} / \mathrm{m}]$ and $K_{p}[\mathrm{kN} / \mathrm{m}]$ have been given in Equations 6 and 7.

$K_{p r}=\frac{1-0.6\left(K_{r} / K_{p}\right)}{1-0.64\left(K_{r} / K_{p}\right)} K_{p}$

\section{Elastic Half Space}

The pile group stiffness observed by Shen et al. [11] assumes that a rigid pile group is embedded in soil 
modeled as an elastic half space. The proposed method, however, has been extended for compressible pile groups. The settlement of a single rigid pile must be calculated in terms of normalized stiffness of a single rigid pile $\left(k_{l r}\right)$ using Equation 2.8. To calculate the settlement of a rigid pile group, $R_{s r}$ (i.e. ratio of rigid pile group settlement to the settlement of rigid single pile under the average load per pile carried by the group) must be obtained from Equation 10.

Using the same manner, the settlement of a single compressible pile must be calculated in terms of normalized stiffness of a single compressible pile $\left(k_{1 c}\right)$ using Equation 11 given in $3 \times 3$ matrix shown in Equation 12. To calculate the settlement of a compressible pile group, Equation 10 must be multiplied by a factor $R\left(=R_{s} / R_{s r}\right)$, termed as a normalized pile group settlement ratio (i.e. ratio of compressible group settlement ratio $\left(R_{s}\right)$ to rigid group settlement ratio $\left(R_{s r}\right)$ ). Furthermore, $R_{s}$ is defined as a ratio of the settlement of compressible pile group to the settlement of a single compressible pile, which allows the use of Equations 11 and 12. In order to calculate $k_{1}, P_{1}$ in Equation 11 or 13 can be obtained by dividing the total load acting on the raft by the number of pile $\left(n_{p}\right)$. In addition, the group of pile is assumed to be connected by a rigid raft at the pile head in the analysis.

$$
\begin{aligned}
& R_{s r}=n_{p}{ }^{\log _{4}\left(2 \pi \rho / r_{o} \zeta^{+} / 1-v_{s}\right)-\log _{4}\left(2 \pi \rho / r_{o} \zeta_{1}+4 /\left(1-v_{s}\right) \zeta_{2}\right)} \\
& k_{1 c}=\frac{P_{1}}{G_{L} r_{o} w_{1}}=\frac{1}{\sum_{i=1}^{3} \sum_{j=1}^{3}[H]^{-1}} \\
& [\text { cell }]=1 / \text { sum (minverse }(\mathrm{H})) \\
& {[H]=\left[\begin{array}{lll}
\frac{2 \pi L \rho}{r_{o} \zeta}+\frac{4}{1-v_{s}} & \frac{\pi L(4 \rho-1)}{3 r_{o} \zeta} & \frac{\pi L(3 \rho-1)}{3 r_{o} \zeta} \\
\frac{\pi L(4 \rho-1)}{3 r_{o} \zeta} & \frac{\pi r_{o} \lambda}{L}+\frac{\pi L(3 \rho-1)}{3 r_{o} \zeta} & \frac{\pi r_{o} \lambda}{L}+\frac{\pi L(8 \rho-3)}{10 r_{o} \zeta} \\
k_{1 r}= & \frac{\pi r_{o} \lambda}{L}+\frac{\pi L(8 \rho-3)}{10 r_{o} \zeta} & \frac{4 \pi r_{o} \lambda}{3 L}+\frac{2 \pi L(5 \rho-2)}{15 r_{o} \zeta}
\end{array}\right]} \\
& \frac{P_{1}}{G_{l} r_{o} w_{1}}=\left[\begin{array}{cc}
\frac{2 \pi L \rho}{r_{o} \zeta}+\frac{4}{1-v_{s}}
\end{array}\right]
\end{aligned}
$$

where:

$k_{1}=$ normalized stiffness of a single pile ( $k_{1 c}$ for compressible pile and $k_{1 r}$ for rigid pile).

$P_{1}=$ average load applied on a single pile $[\mathrm{kN}]$.

$w_{1}=$ settlement of a single pile $[\mathrm{m}]$.

$G_{L}=$ shear modulus at depth $L[\mathrm{kPa}]$.

$L=$ length of pile $[\mathrm{m}]$.

$\rho=$ homogeneity of soil $=G_{\text {avg }} / G_{L}$.

$\zeta=$ load transfer parameter $=\ln \left(r_{m} / r_{o}\right)$.

$\zeta_{1}=\zeta+2 \ln \left(r_{m} / s\right)+\ln \left(r_{m} / \sqrt{2} s\right)$. $\zeta_{2}=1+4 r_{o} / \pi s+2 r_{o} / \sqrt{2} \pi s$

$r_{m}=$ maximum influence radius of pile $[\mathrm{m}]$.

$=2.5 L \rho\left(1-v_{s}\right)+0.7 s \cdot \ln \left(L / r_{o}\right)$ for Equation 18

$=2.5 L \rho\left(1-v_{s}\right)$ for Equations 12 and 13.

$r_{o}=$ radius of pile $[\mathrm{m}]$.

$v_{s}=$ Poisson's ratio of soil.

$\xi=G_{L} / G_{b}$.

$G_{b}=$ shear modulus of soil bellow the base of the pile $[\mathrm{kPa}]$.

$\lambda=$ pile-soil stiffness ratio $=E_{p} / G_{L}$.

$n_{p}=$ number of pile.

\section{Pile Group Modeled by Load-Transfer Curve}

The research on analytical method [11] was continued by Shen and Teh [12] to estimate group stiffness assuming the soil as an elastic half space. Although this method was originally used for pile group foundation, however it will be still introduced since that can be used for the piled raft system [12].

The normalized stiffness of a pile group $\left(k_{G}\right)$ can be given by Equation 14. Matrix $H$ in Equation 14a, is given as $3 \times 3$ matrix, shown in Equation 15. The use of spreadsheet may ease the sum of inverse of the $[H]$ by typing the command given in Equation 14b. Furthermore, for a case with a rigid pile group, the matrix $H$ in Equation 15 becomes a matrix with only one term (i.e. $H_{11}^{-1}$ ) that allows a simpler pile group stiffness (Equation 16) to be calculated.

$k_{G c}=\frac{P_{t}}{G_{L} r_{o} w_{t}}=\frac{1}{\sum_{i=1}^{3} \sum_{j=1}^{3}[H]^{-1}}$

$[$ cell $]=1 /$ sum $(\operatorname{minverse}(\mathrm{H}))$

$[H]=\left[\begin{array}{ccc}2 \mu_{s} \rho+\mu_{b} & \frac{\mu_{s}(4 \rho-1)}{3} & \frac{\mu_{s}(3 \rho-1)}{3} \\ \frac{\mu_{s}(4 \rho-1)}{3} & \mu_{p}+\frac{\mu_{s}(3 \rho-1)}{3} & \mu_{p}+\frac{\mu_{s}(8 \rho-3)}{10} \\ \frac{\mu_{s}(3 \rho-1)}{3} & \mu_{p}+\frac{\mu_{s}(8 \rho-3)}{10} & \frac{4}{3} \mu_{p}+\frac{2 \mu_{s}(5 \rho-2)}{15}\end{array}\right]$

$k_{G r}=\frac{P_{t}}{G_{L} r_{o} w_{t}}=\frac{2 \pi L \alpha_{p}}{r_{o} \zeta}+\frac{4 \alpha_{p b}}{\xi\left(1-v_{s}\right)}$

where:

$k_{G}=$ normalized pile group stiffness $\left(k_{G c}\right.$ for compressible pile group and $k_{G r}$ for rigid pile group).

$w_{t}=$ settlement of piled raft foundation [m].

$P_{t}=$ load applied on the pile group $[\mathrm{kN}]$.

$G_{L}=$ shear modulus at depth $L[\mathrm{kPa}]$.

$L=$ length of pile $[\mathrm{m}]$.

$\rho=$ homogeneity of soil $=G_{\text {avg }} / G_{L}$. 


$$
\begin{aligned}
\mu_{s} & =\frac{\pi \alpha_{p} L}{r_{o} \zeta} . \\
\mu_{b} & =\frac{4 \alpha_{p b}}{\left(1-v_{s}\right) \xi} . \\
\mu_{p} & =\frac{\pi \lambda n_{p}}{L r_{o}} . \\
r_{o} & =\text { radius of pile }[\mathrm{m}] . \\
v_{s} & =\text { Poisson's ratio of soil. } \\
\zeta & =\text { load transfer parameter. } \\
& =\ln \left[L / r_{o}\left(0.25+\left(2.5 \rho\left(1-v_{s}\right)-0.25\right) \xi\right)\right] . \\
\xi & =G_{L} / G_{b} . \\
G_{b} & =\text { shear modulus of soil bellow the base of the } \\
\lambda & =\text { pile }[\mathrm{kPa}] . \\
n_{p} & =\text { nile-soil stiffness ratio }=E_{p} / G_{L} .
\end{aligned}
$$

Stiffness matrix coefficients $\left(\alpha_{p}\right.$ and $\left.\alpha_{p b}\right)$ can be obtained based on the soil flexibility matrix which has been described by Shen et al. [13] using Equations 17 and 18.

$$
\begin{aligned}
& \alpha_{p}=\sum_{i=1}^{n} \sum_{j=1}^{n} f_{s i j}^{-1} \\
& \alpha_{p b}=\sum_{i=1}^{n} \sum_{j=1}^{n} f_{s b i j}^{-1}
\end{aligned}
$$

\section{Differential Settlement of Piled Raft System}

A practical formula to estimate the differential settlement of piled raft foundation under vertical loading was proposed by Randolph and Clancy [14]. The normalized differential settlements $\left(\Delta w / w_{\text {avg }}\right)$ given in Equation 19 and 20 are a function $(f)$ of relative raft-soil stiffness $\left(K_{r s}\right)$ and overall aspect ratio $(O A R)$. The relative raft-soil stiffness given in Equation 21 (for rectangular and square rafts) and 22 (for circular rafts) were proposed by Brown [15]. Having calculated the relative raft stiffness given in Equation 21 or 22, the function (f) must be obtained from Figure 5. The formula to calculate the overall aspect ratio $(O A R)$ proposed by Randolph and Clancy [14] can be seen in Equation 23. In addition, the formula to calculate the overall aspect ratio $(O A R)$, however, was originally made for piled rafts having a square pile group. Extension of using Equation 23 for other shapes of pile group can be done by composing an equivalent square pile group.

$$
\begin{aligned}
& \frac{\Delta w}{w_{\text {avg }}} \approx f \frac{O A R}{4} \text { for } O A R \leq 4 \\
& \frac{\Delta w}{w_{\text {avg }}} \approx f \text { for } O A R>4
\end{aligned}
$$

$$
\begin{aligned}
& K_{r s}=\frac{2\left(1+v_{s}\right) E_{r}}{G} \frac{4 B_{r}}{3 \pi L_{r}}\left(\frac{t_{r}}{L_{r}}\right)^{3} \\
& K_{r c}=\frac{2\left(1+v_{s}\right) E_{r}}{G}\left(\frac{t_{r}}{a}\right)^{3}
\end{aligned}
$$

where:

$v_{s}=$ Poisson's ratio of soil.

$E_{r}=$ elastic modulus of raft $[\mathrm{kPa}]$.

$B_{r}=$ width of raft $[\mathrm{m}]$.

$L_{r}=$ length of raft $[\mathrm{m}]$.

$t_{r}=$ thickness of raft $[\mathrm{m}]$.

$a=$ radius of circular raft $[\mathrm{m}]$.

$G=$ shear modulus of soil beneath the raft $[\mathrm{kPa}]$.

$O A R=\frac{\left\lfloor\left(\sqrt{n_{p}}-1\right) s+d\right\rfloor}{L} \approx \sqrt{\frac{n_{p} s}{L}}$

where:

$n_{p}=$ number of pile.

$s=$ pile spacing $[\mathrm{m}]$.

$d=$ pile diameter $[\mathrm{m}]$.

$L=$ pile length $[\mathrm{m}]$.

\section{Design Concept for Settlement Reduction}

The design trend of piled raft foundation is basically changing to piles as settlement reducers, instead of taking a major portion of the foundation load. A current design trend of piled raft foundation is to utilize the piles below the raft to reduce the settlement of the foundation and reduce the net increase pressure in the subsoil. This trend composes an optimum pile configuration to satisfy design philosophy of piled raft foundation. In order to minimize the settlement of piled raft system, the following design considerations must be taken into account:

1. The raft foundation must be able to provide an enough bearing capacity against the applied working load [16].

2. The primary objective is to reduce the differential settlement of the raft by placing few piles up to an acceptable value [17] rather than reducing the average settlement.

3. In case of piled raft on soft soil, imposing adequate temporary surcharging and preloading techniques prior to the piled raft foundation will effectively reduce the average settlement of the piled raft foundation [16]. This combination is necessary to satisfy the performance of the foundation.

4. The settlement reducing piles are designed as friction piles and this eliminate a risk of structural failure or an inadequacy of piles due to negative skin friction [16].

5. Few piles needed to satisfy the differential settlement must be located strategically to reduce as much the stress concentration on the soil [16]. 


\section{Experimental Study on Piled Raft System}

A study of relation between the settlement of piled rafts with a varying pile length and/or spacing, and piled rafts with an uniform pile length and spacing has performed in this study. Moreover, it comprises of some objectives of the study to achieve for understanding and develop the relation and prediction of the settlements into design. The objectives of the study are as follows:

- Finding the influence of design parameters $\left(A_{p}\right.$, $n L$, and $\left.B_{g} / B_{r}\right)$ on the settlement of piled rafts through some case studies.

- Obtaining and summarizing the relation among design parameters $\left(A_{p}, n L\right.$, and $\left.B_{g} / B_{r}\right)$.

- Proposing design charts and procedures to utilize the design parameters $\left(A_{p}, n L\right.$, and $\left.B_{g} / B_{r}\right)$ to predict the settlement of piled raft foundation.

- Evaluating the use of the some practical analytical methods in terms of applicability.

\section{Design of Bench Scale Test}

\section{Dimension of Miniature and Material Properties}

The raft thickness of $1.5 \mathrm{~cm}$ was chosen by considering an impression of rigid raft. The lengths of pile were determined to be $10 \mathrm{~cm}$ and $15 \mathrm{~cm}$ (Figure 7) by considering the application of sort piles and workability when pushing the piled raft miniature into the soil. The longer the piles the harder it will be, because the soil used was sand, which may exhibit dilation at higher relative density $\left(D_{r}\right)$. During pushing, the piled raft miniature will increase the surrounding density. In spite of technical aspect described above, the miniature was designed considering application of short piles below the raft. The overall miniature was scaled up to 1: 75 after considering all the aspects. This was merely design to have relative raft-soil stiffness $\left(K_{r s}\right) \geq 54$ (as rigid raft) as part of the assumption of the study.

The piled raft miniature made of aluminum was used because it is light, yet strong and durable. Figure 7 has shown the piled raft miniature with dimension. Eventually, the material properties of piled raft miniature were adopted from some reference values as given in Table 2 .

Table 2. Properties of Material of Piled Raft Miniature

\begin{tabular}{lll}
\hline Property & $\begin{array}{l}\text { Value and } \\
\text { Unit }\end{array}$ & Remarks \\
\hline Unit weight $(\gamma)$ & $27.2 \mathrm{kN} / \mathrm{m}^{3}$ & $\begin{array}{l}\text { United States Steel } \\
\text { Corporation }\end{array}$ \\
Elastic Modulus $(E)$ & $70,000 \mathrm{MPa}$ & $\begin{array}{l}\text { United States Steel } \\
\text { Corporation }\end{array}$ \\
Poisson's ratio $(v)$ & 0.33 & \\
\hline
\end{tabular}

The engineering properties of the soil can be seen in Table 3. During the test the sand was mounted in an acrylic chamber $(50 \mathrm{~cm}$ x $50 \mathrm{~cm}$ x $50 \mathrm{~cm}$ ) up to $30 \mathrm{~cm}$ high. A small light weight plate was the used to gently compact the surface to the soil horizontally. The sand was furthermore classified as SP (poorly graded sand) with low relative density $\left(D_{r}\right)$ which can represent soft ground.

Table 3. Material Properties of Soil

\begin{tabular}{lll}
\hline Property & Value and Unit & Remarks \\
\hline Total unit weight $(\gamma)$ & $14.39 \mathrm{kN} / \mathrm{m}^{3}$ & - \\
Cohesion $(c)$ & $\begin{array}{l}0.2 \mathrm{kPa} \\
(\text { minimum })\end{array}$ & \\
& $32^{\circ}$ & \\
Internal friction angle $(\varphi)$ & 0.32 & \\
Poisson's ratio $\left(v_{s}\right)$ & $5000 \mathrm{kPa}$ & - \\
Deformation modulus $\left(E_{s}\right)$ & $0 \%$ & \\
Water content & $0 \%$ & Standard \\
Specific gravity & 2.64 & proctor \\
Relative density & $30.71 \%$ & USCS \\
& &
\end{tabular}

\section{Configurations of Piled Raft System}

The pile configurations are divided into three groups of case study (Figure 6), termed as cases 1, 2 and 3. In addition, a group must have the same ratio of width of pile group to width of raft $\left(\boldsymbol{B}_{g} \boldsymbol{B}_{r}\right)$ and total length of pile $(\boldsymbol{n} \boldsymbol{L})$, but different total area of pile $\left(A_{p}\right)$. Every case $\boldsymbol{a}$ of each group has uniform pile length $(L)$ and spacing $(s)$, however, cases $\boldsymbol{b}$ to $\boldsymbol{c}$ or $d$ may have different pile length $(L)$ and spacing $(s)$. The comparison and correlation of settlement behavior of every case $\boldsymbol{a}$ to other cases will be studied by involving some design parameters $\left(\boldsymbol{B}_{\boldsymbol{g}} \boldsymbol{B} \boldsymbol{B}\right.$, $\boldsymbol{A}_{\boldsymbol{p}}$, and $\boldsymbol{n L}$ ). Another important rule depicted in Figure 6 is that the group of pile of every case $\boldsymbol{b}, \boldsymbol{c}$, or $\boldsymbol{d}$ has axis of symmetry, as well as for every case $\boldsymbol{a}$. eventually, the list of design parameters of every group of case study is given in Table 4. In conclusion, the experimental case studies in Figure 6 (cases 1, 2, and 3) were designed with fixed $\boldsymbol{B}_{\boldsymbol{g}} \boldsymbol{B}_{\boldsymbol{r}}$ and $\boldsymbol{n} \boldsymbol{L}$ for each group. Each case, however, has different $\boldsymbol{A}_{\boldsymbol{p}}$.

In order to study the use of the design parameters $\left(A_{p}, n L\right.$, and $\left.B_{g} / B_{r}\right)$, some pile raft configurations were designed (Figure 6). The pile raft miniature used (Figure 7) was made of aluminum provided with two different lengths of pile (10 and $15 \mathrm{~cm}$ ). Furthermore, the number of piles was selected to be 25 (maximum) with spacing of $4 \mathrm{~d}(\mathrm{~d}=$ diameter of pile $=0.8 \mathrm{~cm})$ for convenient and workability purposes. Furthermore, the schematic diagram of the bench scale test can be seen in Figure 7 . 

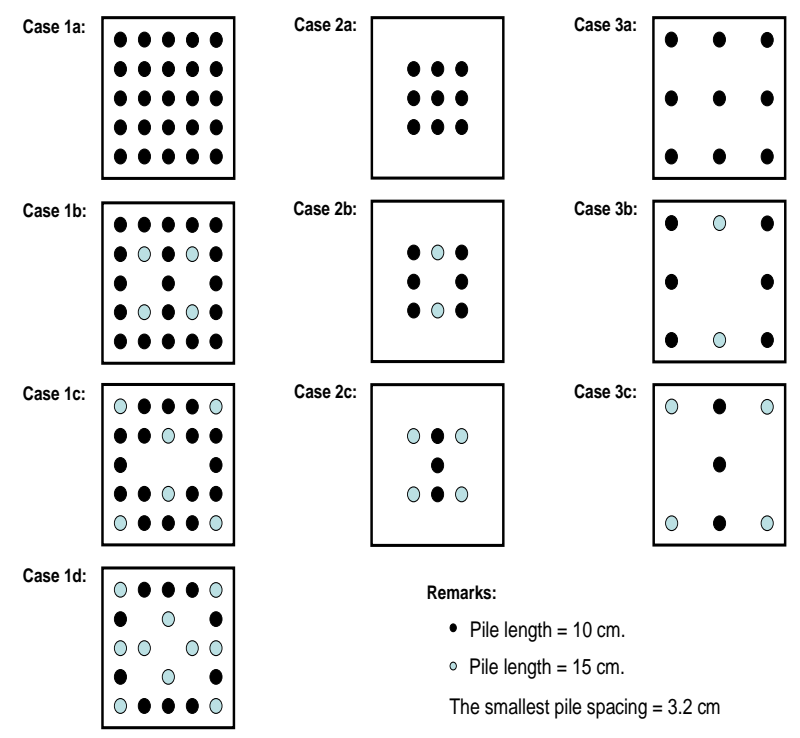

Figure 6. Configuration of Piled Raft System.

Table 4. Alternative for Parameter Design

\begin{tabular}{|c|c|c|c|c}
\hline Case & $\mathbf{B}_{\mathbf{g}} / \mathbf{B}_{\mathbf{r}}$ & $\mathbf{A}_{\mathbf{p}}\left(\mathbf{c m}^{2}\right)$ & $\mathbf{A}_{p} / \mathbf{n L}(\mathbf{c m})$ & $\mathbf{n L}$ \\
\hline 1a & 0.80 & 12.566 & 0.050 & 250 \\
\hline 1b & 0.80 & 11.561 & 0.046 & 250 \\
\hline 1c & 0.80 & 11.058 & 0.044 & 250 \\
\hline 1d & 0.80 & 10.051 & 0.040 & 250 \\
\hline 2a & 0.40 & 4.524 & 0.050 & 90 \\
\hline 2b & 0.40 & 4.021 & 0.045 & 90 \\
\hline 2c & 0.40 & 3.519 & 0.039 & 90 \\
\hline 3a & 0.80 & 4.524 & 0.050 & 90 \\
\hline 3b & 0.80 & 4.021 & 0.045 & 90 \\
\hline 3c & 0.80 & 3.519 & 0.039 & 90 \\
\hline
\end{tabular}

\section{Results and Discussions}

The model simulations for the bench scale tests were conducted using 2D FEM plane strain program (PLAXIS Finite Element Code v. 8.2) to account the part of piled raft foundation which is located out of plane. The load was idealized as uniform one and a standard boundary condition was used according to program code.

The part of piled raft foundation which is out of plane is considered having average flexural (EI avg) and axial (EA avg) stiffness. Prakoso and Kulhawy [18] proposed to use average plane strain stiffness on $2 \mathrm{D}$ plain strain analysis. The concepts are adopted in Equations 24 and 25 against bending and axial forces for modeling an out of plane row of piles as a beam element. The input data for material property in numerical simulation are taken from Tables 3 and 4.

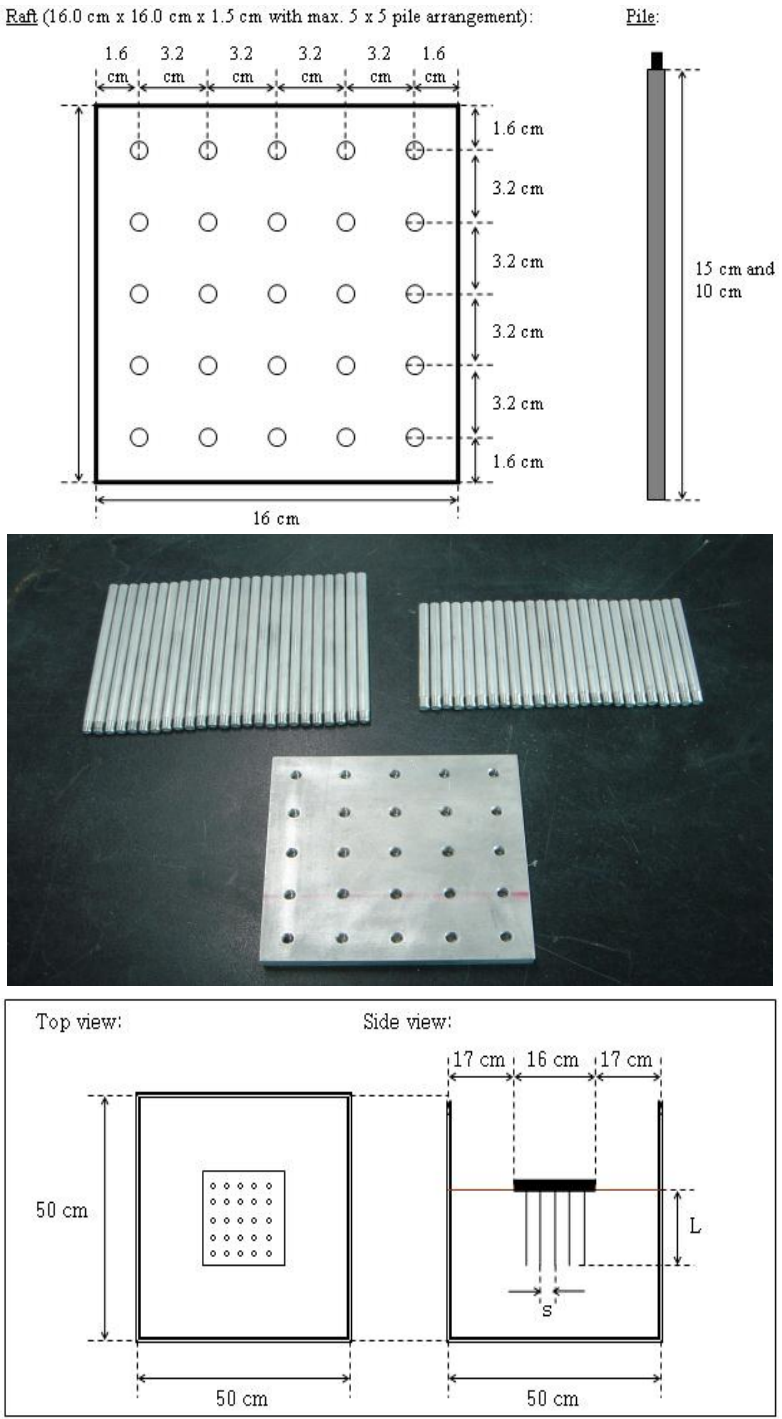

Figure 7. Pile Raft Miniatures and Dimension

$$
\begin{aligned}
& E I_{\text {avg }}=\frac{E_{p} \times I_{1 p} \times n_{p 1 r}}{L_{r}} \\
& E A_{\text {avg }}=\frac{E_{p} \times A_{1 p} \times n_{p 1 r}}{L_{r}}
\end{aligned}
$$

where:

$E I_{\text {avg }}=$ average plane strain flexural stiffness $\left[\mathrm{kNm}^{2}\right]$.

$E A_{\text {avg }}=$ average plane strain axial stiffness $[\mathrm{kN}]$.

$E_{p} \quad=$ elastic modulus of pile $[\mathrm{kPa}]$.

$I_{1 p}=$ moment of inertia of one pile in bending direction $\left[\mathrm{m}^{4}\right]$.

$A_{1 p}=$ area of one pile $\left[\mathrm{m}^{2}\right]$.

$n_{p 1 r}=$ number of pile of a row in out of plane direction.

$L_{r} \quad=$ length of raft $[\mathrm{m}]$.

Three practical formulas proposed by Fleming et al. [7] Shen et al. [11], and Shen et al. [12], have been selected. The analytical methods, however, are limited to piled rafts with uniform pile length $(L)$ and 
spacing $(s)$, so that the evaluations of sensitivity of analytical method with bench scale test results are performed only for cases $1 a, 2 a$, and $3 a$ (see Figure 6 ). The use of analytical method for other case studies was not recommended due to the variation of pile spacing $(s)$ and lengths $(L)$. The detail of every formula mentioned is not described in this paper, since the reader can easily refer to text books and journals. In addition, the input data for analytical methods was taken from Tables 2 and 3.

\section{Settlement Behaviors}

The experimental load-settlement curves were idealized using quadratic. That use of quadratic polynomials with $R^{2}$ close to one show that the soil mostly performs hyperbolic-non-linear behavior. The results expressed in Figures $8-17$ shows that the load-settlement curves obtained experimentally and numerically are in good agreement. The comparisons with analytical methods have also resulted in good agreement as well (Figure 18 - 23). In Figures 18 23 , it give some ideas of the best fit analytical methods. The method proposed by Fleming et al. [7] or Shen et al. [11] are best-fit for estimating the settlement of piled rafts with greater $B_{g} / B_{r}$ (in this case, $B_{g} / B_{r}=0.80$. When $B_{g} / B_{r}$ is smaller (in this case, $B_{g} / B_{r}=0.40$; see Figure 19 ), the formula proposed by Shen et al. [12] is best-fit.

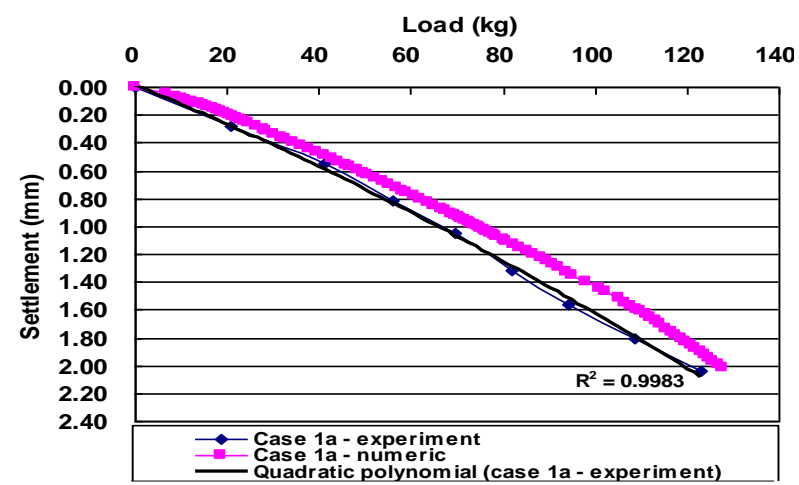

Figure 8. Numerical and Experimental Load- Settlement Curves of Case 1a

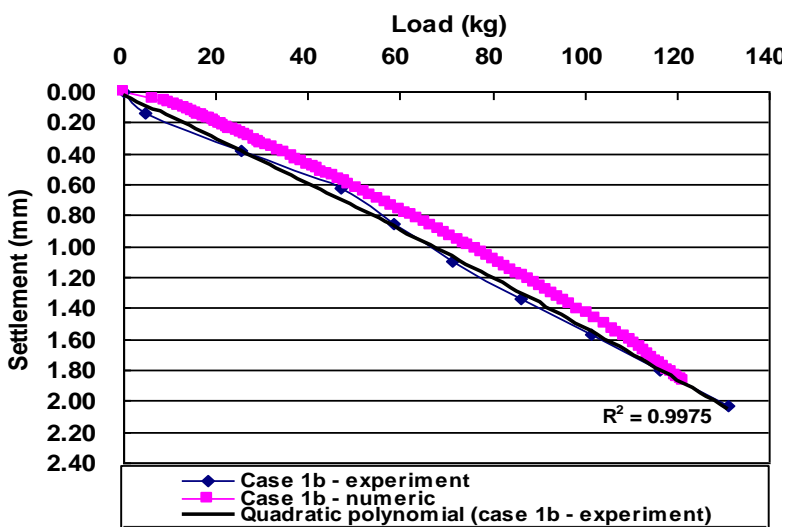

Figure 9. Numerical and Experimental Load-Settlement Curves of Case 1b.

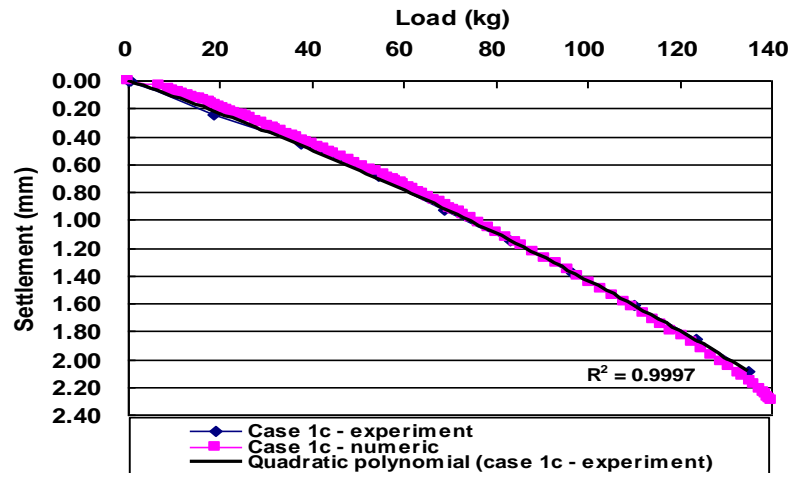

Figure 10. Numerical and Experimental Load-Settlement Curves of Case 1c

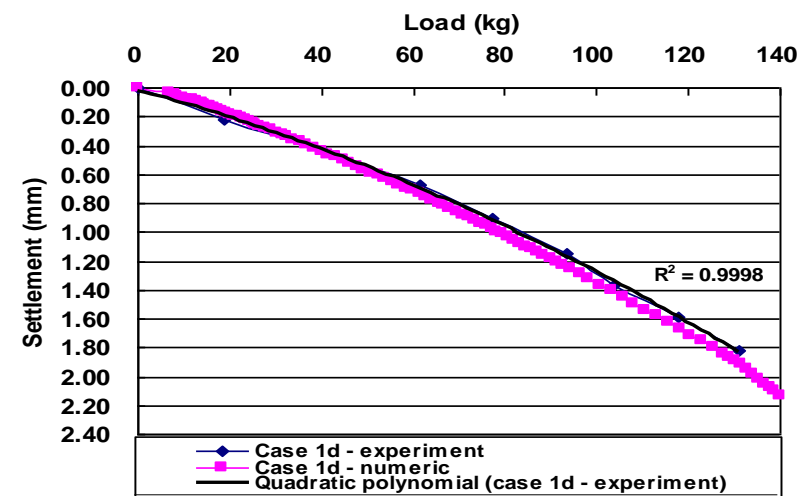

Figure 11. Numerical and Experimental Load-Settlement Curves of Case $1 \mathrm{~d}$.

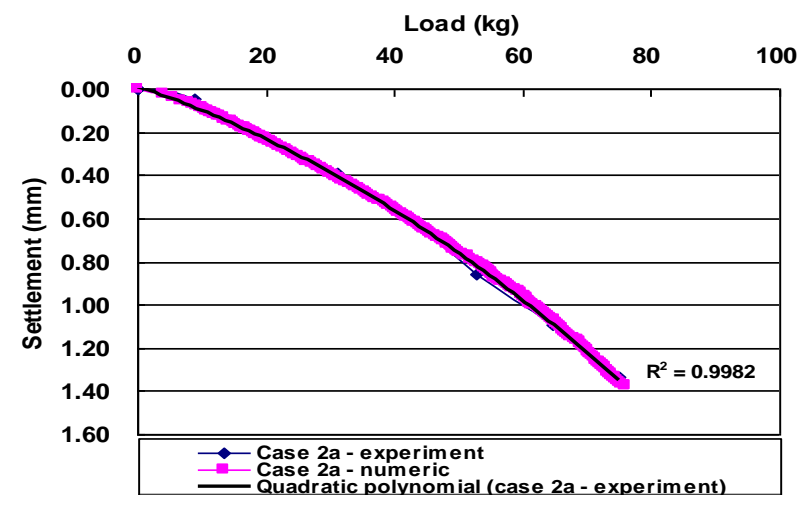

Figure 12. Numerical and Experimental Load-Settlement Curves of Case 2a.

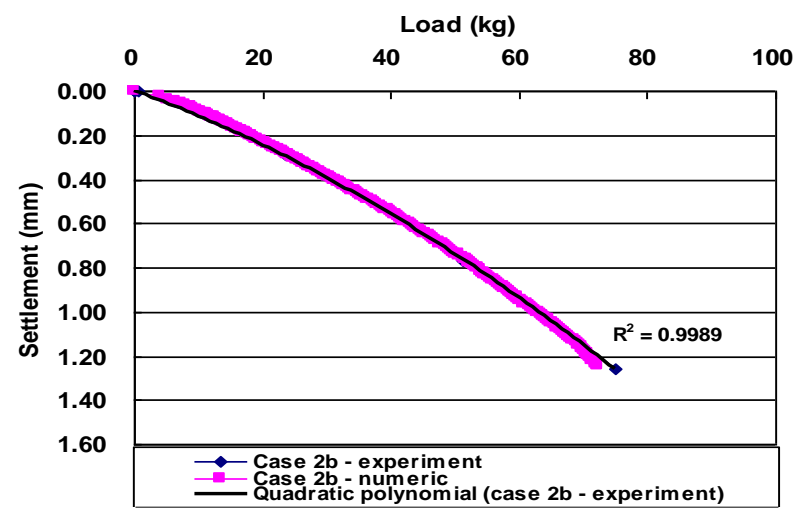

Figure 13. Numerical and Experimental Load-Settlement Curves of Case $2 b$ 


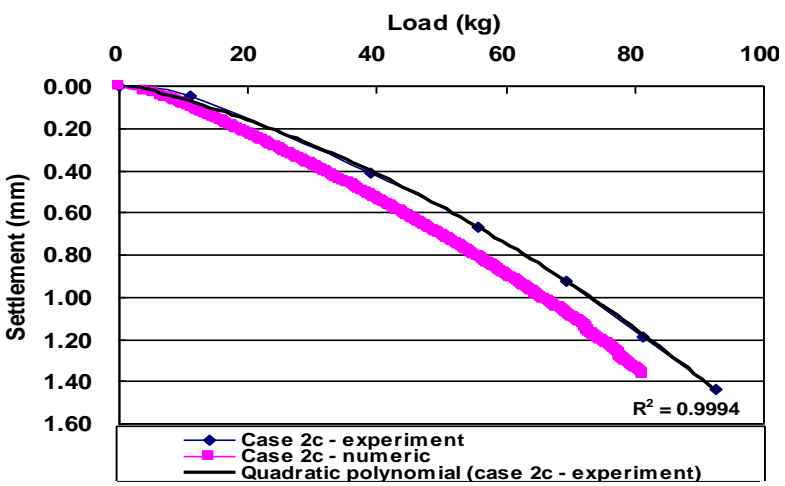

Figure 14. Numerical and Experimental Load-Settlement Curves of Case 2c.

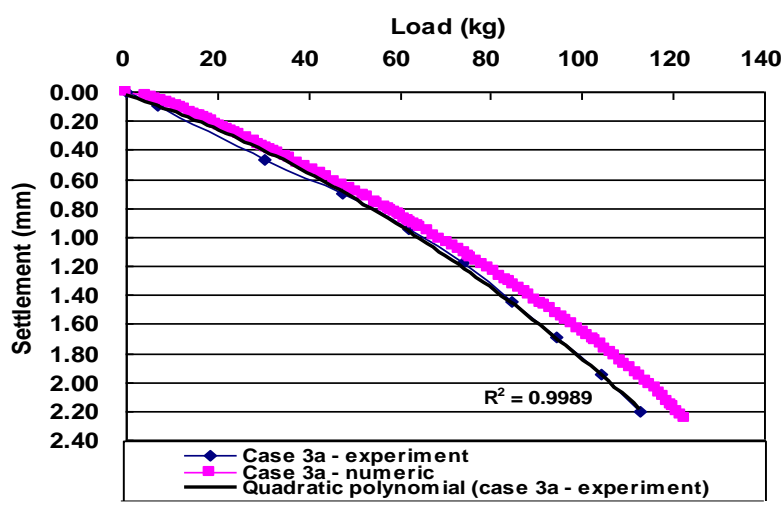

Figure 15. Numerical and Experimental Load-Settlement Curves of Case 3

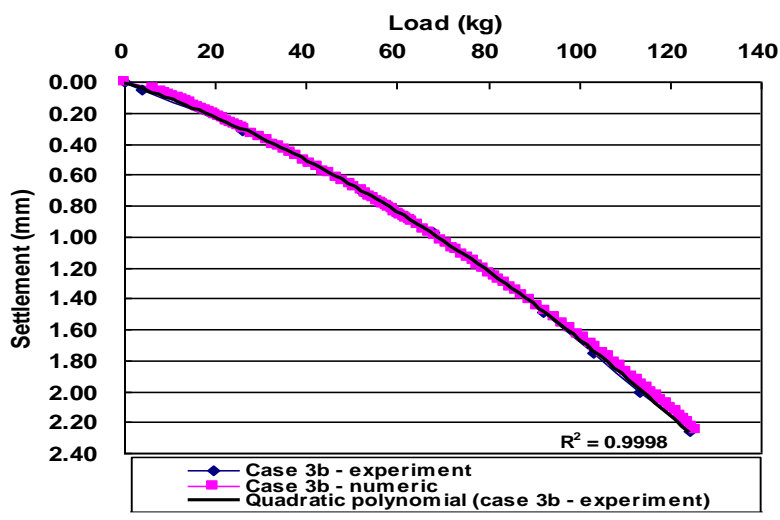

Figure 16. Numerical and Experimental Load-Settlement Curves of Case $3 \mathrm{~b}$.

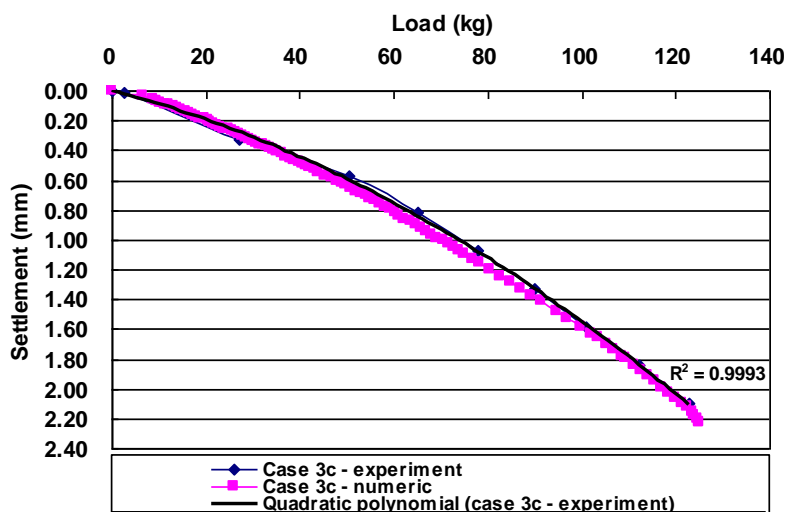

Figure 17. Numerical and Experimental Load-Settlement Curves of Case $3 \mathrm{c}$

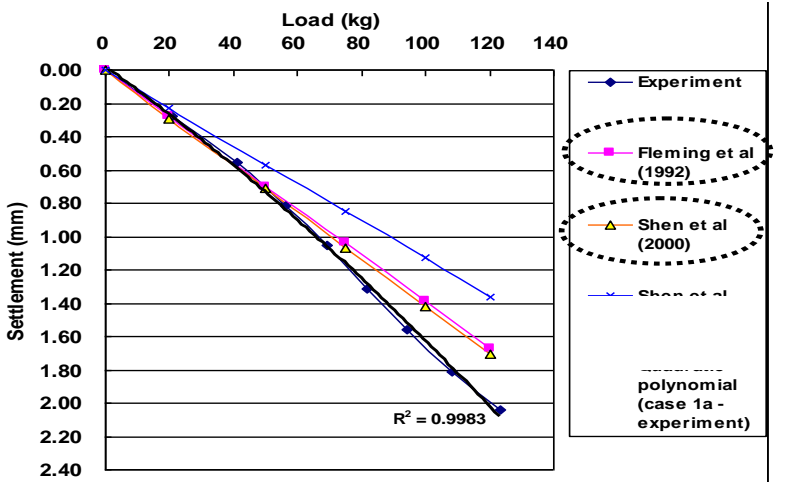

Figure 18. Analytical (linear) and Experimental (NonLinear) Load-Settlement Curves of Case 1a.

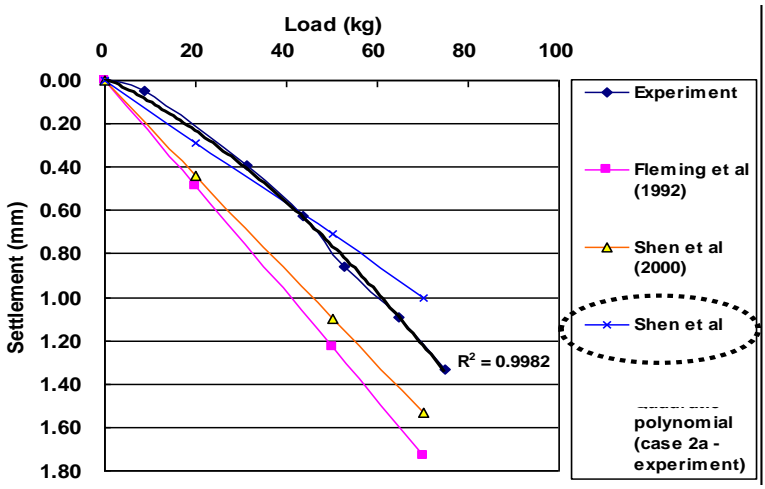

Figure 19. Analytical (Linear) and Experimental (NonLinear) Load-Settlement Curves of Case 2a.

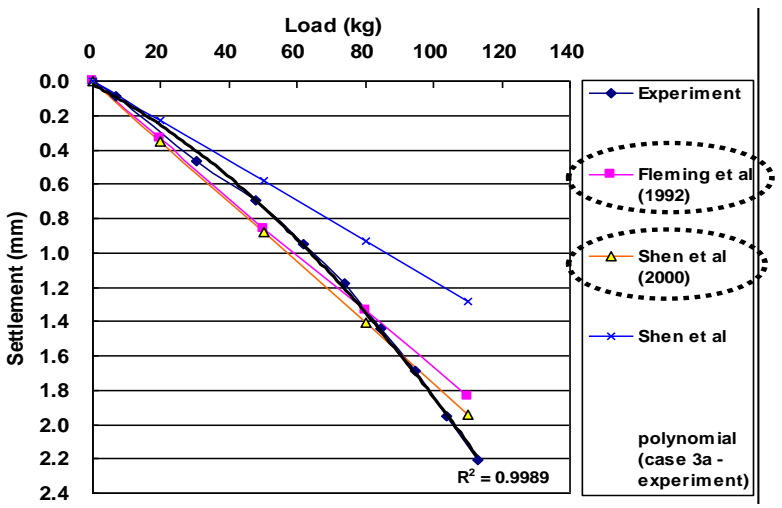

Figure 20. Analytical (Linear) and Experimental (NonLinear) Load-Settlement Curves of Case 3a

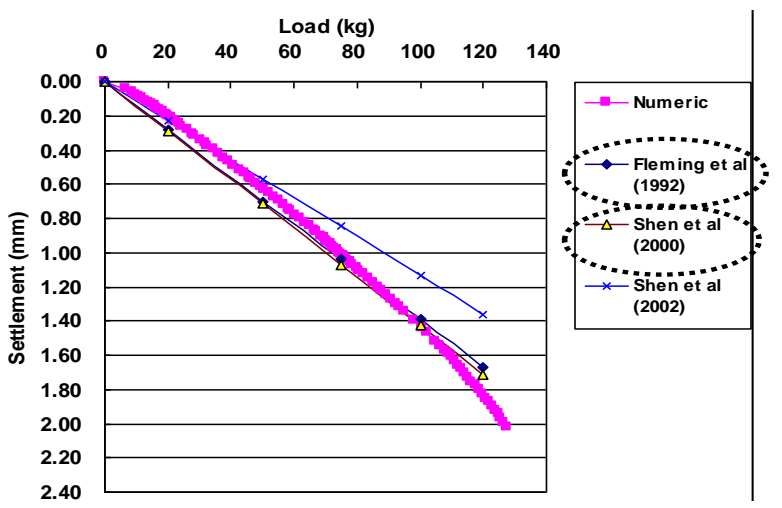

Figure 21. Analytical (Linear) and Numerical (NonLinear) Load-Settlement Curves of Case 1a. 


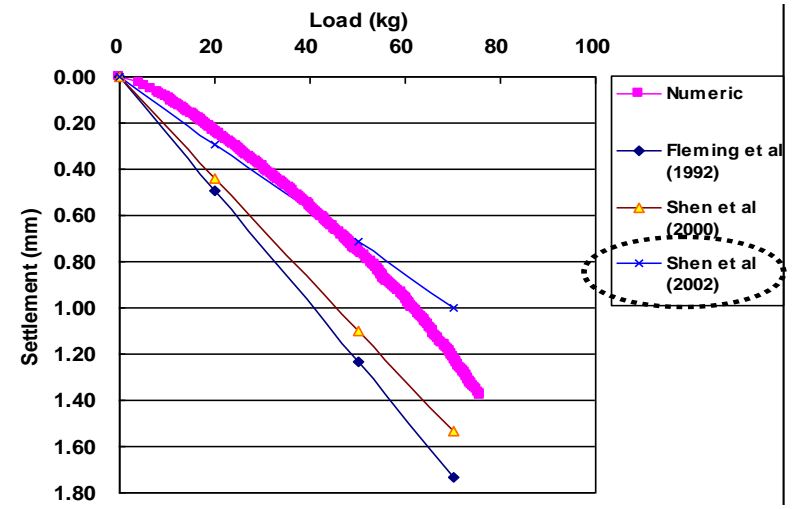

Figure 22. Analytical (Linear) and Numerical (NonLinear) Load-Settlement Curves of Case 2a

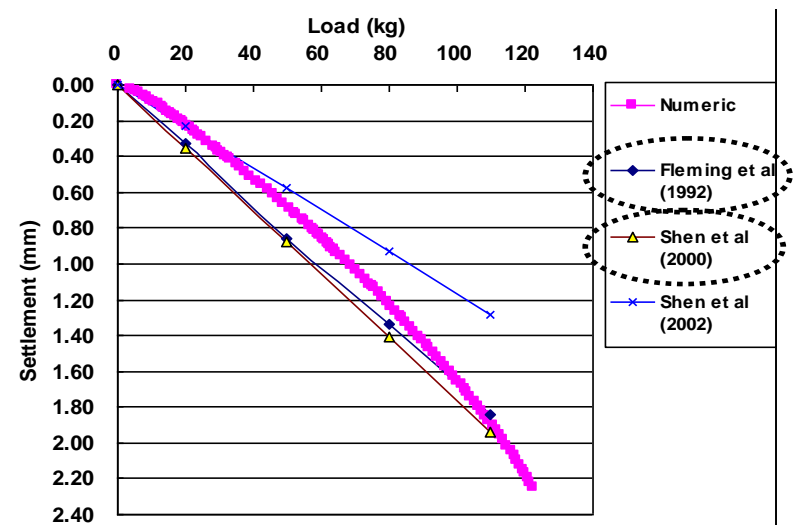

Figure 23. Analytical (Linear) and Numerical (NonLinear) Load-Settlement Curves of Case 3a

\section{Normalized Settlement vs. Normalized $A_{p} / n L$}

Having further analyzed the load-settlement curves, the settlements of piled raft with varying pile lengths were normalized with those of piled raft with a uniform length. The normalized settlements obtained were related to the corresponding normalized $A_{p} / n L$. Moreover, the results show that the relation between normalized settlement and normalized $A_{p} / n L$ are not sensitive to different load levels (Figures 24 to 29). Based on this phenomenon, it is more convenient to express the normalized settlements as the average normalized settlement form now on.

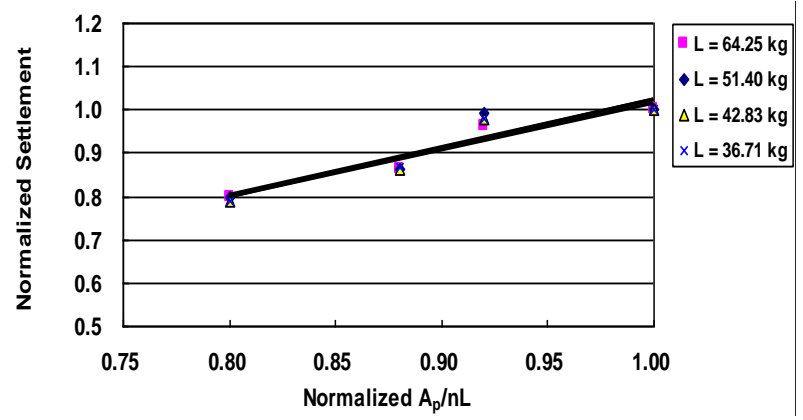

Figure 24. Normalized Settlement vs. Normalized $A_{p} / n L$ of Case 1 for Different Load Levels Experimentally

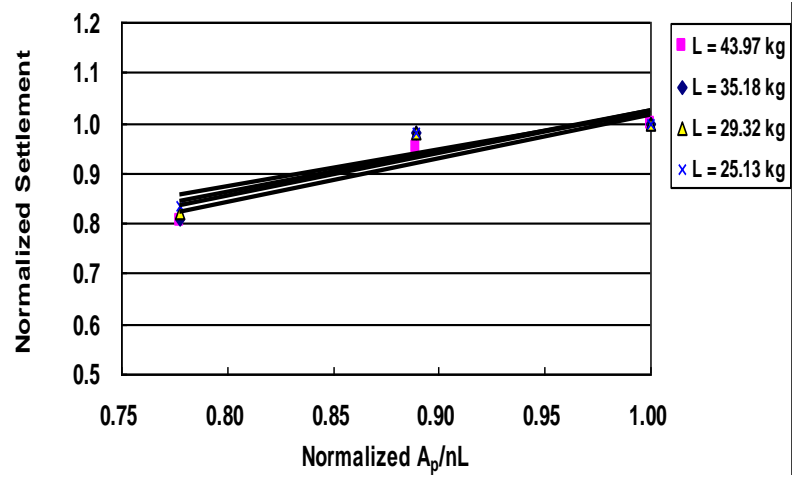

Figure 25. Normalized Settlement vs. Normalized $A_{p} / n L$ of Case 2 for Different Load Levels Experimentally

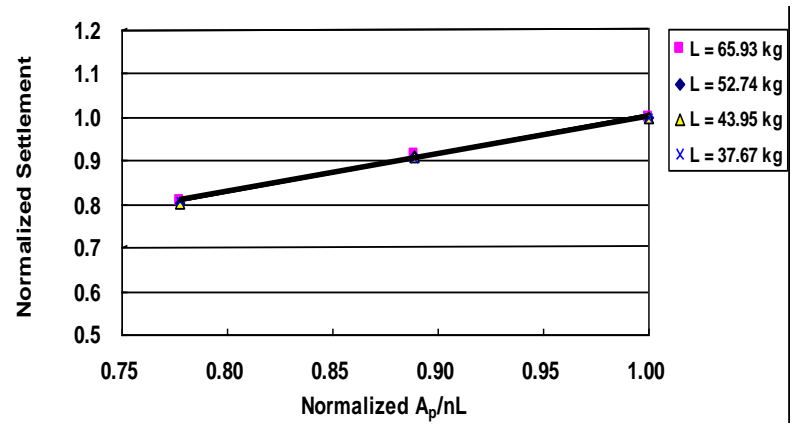

Figure 26. Normalized Settlement vs. Normalized $A_{p} / n L$ of Case 3 for Different Load Levels Experimentally

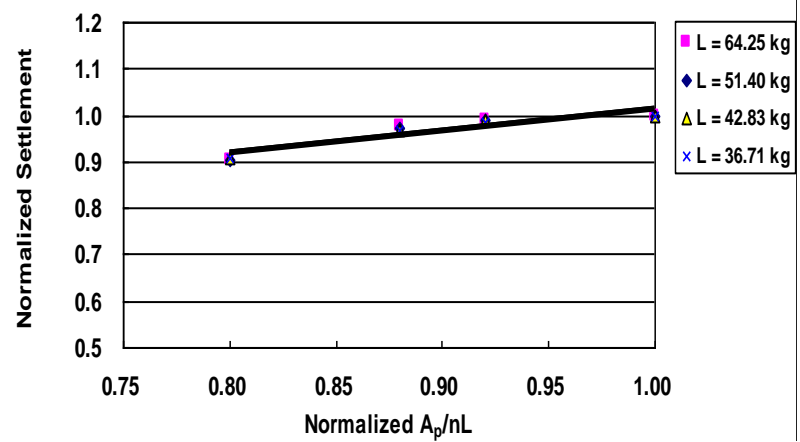

Figure 27. Normalized Settlement vs. Normalized $A_{p} / n L$ of Case 1 with Different Load Levels Numerically

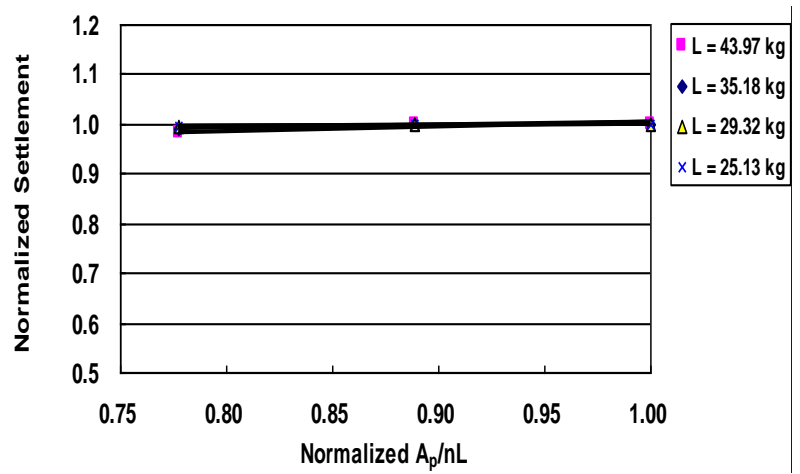

Figure 28. Normalized Settlement vs. Normalized $A_{p} / n L$ of Case 2 with Different Load Levels Numerically. 


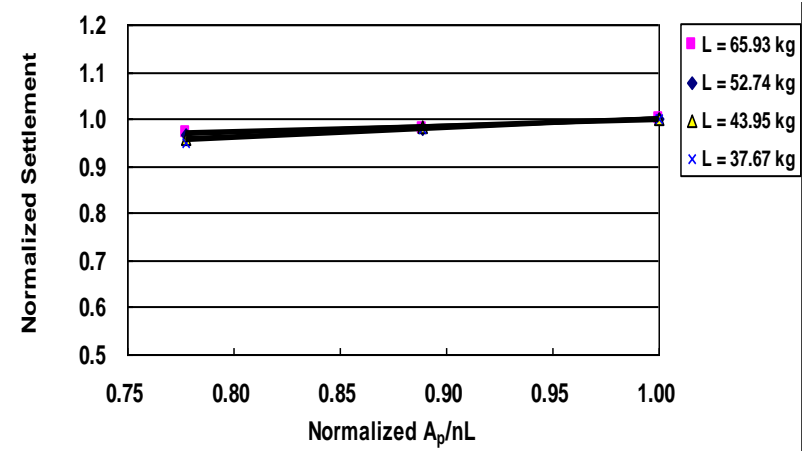

Figure 29. Normalized Settlement vs. Normalized $A_{p} / n L$ of Case 3 with Different Load Levels Numerically

\section{Average Normalized Settlement vs. Norma- lized $A_{p} / n L$.}

The average normalized settlements obtained from $2 \mathrm{D}$ plain strain analysis are, in fact, not too sensitive with the change of the normalized $A_{p} / n L$. These phenomena are slightly different form those obtained from bench scale tests (Figure 30). This may attribute that $2 \mathrm{D}$ plain strain may underestimate the change of average normalized settlements. The influence of variation of $B_{g} / B_{r}$ from the case study (0.4 to 0.8) is also small, shown that the distribution of data in Figure 30.

Average Normalized Settlement vs. Normalized $A_{p} / n L$

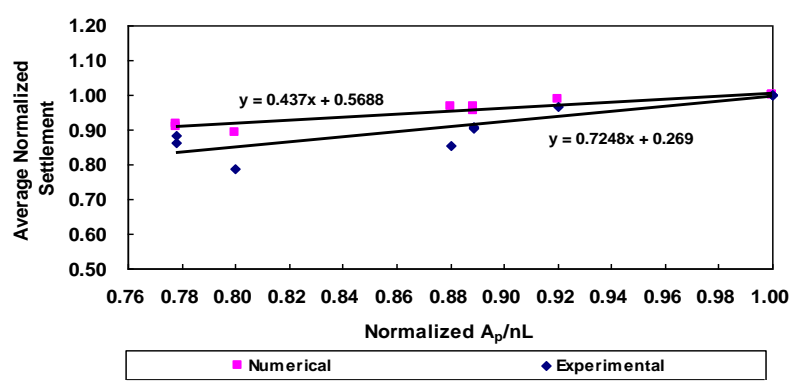

Figure 30. Average Normalized Settlement and Normalized $A_{p} / n L$.

Based on the results of bench scale tests and numerical simulations, the relation between the average normalized settlements for given limited range of the normalized $A_{p} / n L$ can be predicted or idealized (Figure 31). The prediction of settlement of piled raft with varying pile length has been finally simplified by referring to pile raft with a uniform pile length. The relation given in Figure 31 can be used by following some rules, those are when both pile rafts with a varying pile length and uniform pile length have the same $B_{g} / B_{r}$ and $n L$. Once $B_{g} / B_{r}$ and $n L$ have been fixed, the only variable left is $A_{p}$ of pile rafts with a varying and uniform pile lengths. Since the settlement of pile raft with a uniform pile length can be predicted with some analytical formulas (shown in Figures 18 to 23), the settlement of pile raft with varying pile length can be estimated by referring to Figure 31. The relation between average normalized settlement and normalized $A_{p} / n L$ can be finally expressed in Equation 26.

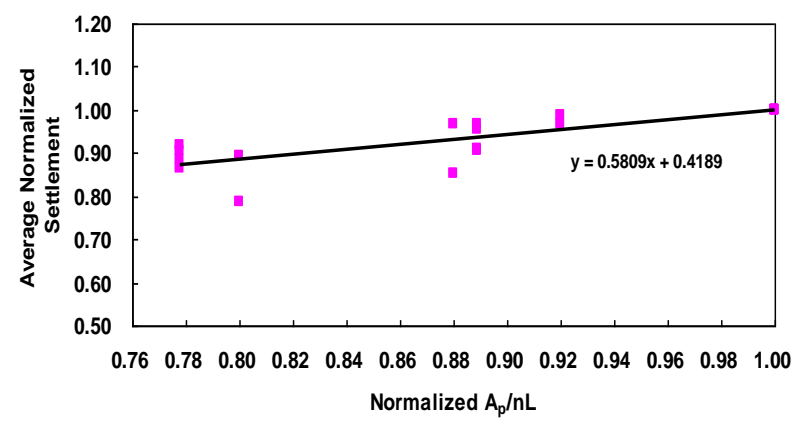

Figure 31. Prediction of Average Settlement by $A_{p} / n L$.

$S S=a \cdot A L+b$

where:

$\mathrm{SS}=$ average normalized settlement of piled raft with a varying pile length to piled raft with a uniform pile length. These two piled rafts must have the same $B_{g} / B_{r}$ and $n L$.

$\mathrm{AL}=$ normalized $A_{p} / n L$ of piled raft with a varying pile length to piled raft with a uniform pile length. These two piled rafts must have the same $B_{g} / B_{r}$ and $n L$, as well.

$a, b=$ experimental constants varies from geotechnical properties $(a=0.5809 ; b=0.4189)$ for $0.78 \leq x \leq 1.00$.

\section{Conclusions and Discussions}

A study on the prediction of settlement of the piled raft based on the pile dimension has been performed. The settlement of piled raft with a varying pile length and the settlement of piled raft with an uniform pile length have been analyzed in term of relation of normalized average normalized settlement and normalized $A_{p} / n L$. The relations were composed through the proposed design parameters: the total area of pile $\left(A_{p}\right)$, the total length of pile $(n L)$, and the ratio of the width of piled group to the width of raft $\left(B_{g} / B_{r}\right)$ or width ratio. Moreover, there are some important concluding remarks to be highlighted, as follows:

- The settlement of piled rafts with a varying pile length can be predicted based on the settlement of piled rafts with an uniform pile length by using parameter $A_{p}$ and $n L$ for the same $B_{g} / B_{r}$ and $n L$. The normalized settlements are insensitive to different load levels. One may confidentially predict the settlement using Figure 31 at various load levels. The normalized settlements have a linear relationship with the normalized $A_{p} / n L$. 
- The pile resistances is greater than the resistance of raft as the settlement progresses. The raft is in direct contact with the soil will show higher portion of load taken by the raft at early stage and slowly reduce as the pile resistances are mobilized (Figure 2). In addition, "with a reduction of interface strength" refers to slip at the interface of soil and pile taken into account. "without a reduction of interface strength" means interface strength of soil and pile is the same as that of soil.

- In practical design of piled raft system, it is recommended that the standard for determining the working load share rate of piles and raft should be studied by using the collected field measurements. In domestic, piles and rafts are designed by two different fields and it surplus designed in economically. It is preferable to use of piled raft system to reduce expenses for foundation rather than the end bearing piles.

\section{References}

1. Ahner, C., Soukhov, D., and Konig, G., Reliability Aspect Design of Combined Piled-Raft Foundation (CPRF), 2nd International PhD Symposium in Civil Engineering, Budapest, 1998.

2. Reul, O. and Randolph, M.F., Design Strategies for Piled Rafts Subjected to Nonuniform Vertical Loading, Journal of Geotechnical and Geoenvironmental Engineering, 130(1), ASCE, 2004, pp. 1-13.

3. Reul, O., Numerical Study of the Bearing Behavior of Piled Rafts, International Journal of Geomechanics, 4(2), ASCE, 2004, pp. 59-68.

4. Poulos, H.G., Piled Raft Foundations: Design and Application, Geotechnique, 51, 2001, pp. 95113.

5. Poulos, H.G. and Davis, E.H., Pile Foundation Analysis and Design, John Wiley \& Sons, New York, 1980, pp. 250-264.

6. Harr, M.E., Foundations of Theoretical Soil Mechanics, McGraw-Hill Incorporated, New York, 1966.

7. Fleming, W.G.K., Weltman, A.J., Randolph, M. F., and Elson, W.K., Piling Engineering $2^{\text {nd }}$ Edition, Surrey University Press, London, 1992, p. 390.
8. Randolph, M.F. and Wroth, C.P., Analysis of Deformation of Vertically Loaded Piles, Journal of the Geotechnical Engineering Division, 104(12), 1978, pp. 1465-1488.

9. Foundation Design and Construction - Geo Publication No. 1, Geotechnical Engineering Office, Civil Engineering and Development Department, Hong Kong, 2006.

10. Clancy, P. and Randolph, M.F., An Approximate Analysis Procedure for Piled Raft Foundations, International Journal for Numerical and Analytical methods in Geomechanics, 17(12), 1993, pp. 849-869.

11. Shen, W.Y., Chow, Y.K., and Lee, K.Y., Practical Method for Settlement Analysis of Pile Groups, Journal of Geotechnical and Geoenvironmental Engineering, 126(10), ASCE, 2000, pp. 890-897.

12. Shen, W.Y. and Teh, C.I., Practical Solution for Group Stiffness Analysis of Piles, Journal of Geotechnical and Geoenvironmental Engineering, 128(8), ASCE, 2002, pp. 692-698.

13. Shen, W.Y., Chow, Y.K., and Yong, K.Y., A Variational Approach for Vertical Deformation Analysis of Pile Group, International Journal for Numerical and Analytical Methods in Geomechanics, 21(11), 1997, pp. 741-752.

14. Randolph, M.F. and Clancy, P., Design and Performance of a Piled Raft Foundation, in Vertical and Horizontal Deformations of Foundations and Embankments, American Society of Civil Engineers, 1994, pp. 314-321.

15. Brown, P.T., The Significance of StructureFoundations Interaction, The Second AustraliaNew Zealand Conference in Geomechanics, Brisbane, Australia, 1975, pp. 79-82.

16. Tan, Y.C. and Chow, C.M., Design of Piled Raft Foundation on Soft Ground, GSM-IEM Forum, 2004.

17. Liew, S.S., Gue, S.S., and Tan, Y.C., Design and Instrumentation Results of A Reinforcement Concrete Piled Raft Supporting 2500 Ton Oil Storage Tank on Very Soft Alluvium Deposits, $9^{\text {th }}$ International Conference on Piling and Deep Foundations, Nice, 2002

18. Prakoso, W.A. and Kulhawy, F.H., Contribution to Piled Raft Foundation Design. Journal of Geotechnical and Geo-environmental Engineering,. 127(1), ASCE, 2001, pp. 17-24. 